\title{
Comparison between Self-reported and Objective Measures on Speech Characteristics in Patients with Parkinson's Disease
}

\author{
Hyeon Ah Kima, Sun Woo Kim ${ }^{\text {, Ji Hye Yoon }}$ \\ ${ }^{a}$ Department of Speech Pathology, Graduate School of Health Sciences, Hallym University, Chuncheon, Korea \\ ${ }^{b}$ Department of Speech-Language Habilitation, Daelim University College, Anyang, Korea \\ 'Division of Speech Pathology and Audiology, Hallym University, Chuncheon, Korea
}

Correspondence: Ji Hye Yoon, $\mathrm{PhD}$

Division of Speech Pathology and Audiology, Hallym University, 1 Hallimdaehak-gil,

Chuncheon 24252, Korea

Tel: $+82-33-248-2224$

Fax: $+82-33-256-3420$

E-mail: j.yoon@hallym.ac.kr

Received: November 1, 2017

Revised: November 24, 2017

Accepted: November 24, 2017

This research was supported by Hallym University Research Fund in 2017 (No. HRF-201711-011)
Objectives: This study used a self-evaluation questionnaire survey on speech characteristics with patients with Parkinson's disease, and investigated the correlation between the survey's self-reported results and clinicians' speech evaluations. Methods: Forty patients with Parkinson's disease were divided into an mild group and a moderate/severe group according to limb hypokinesia severity. Then, speech tasks of maximum phonation time, diadochokinesia, and paragraph reading were conducted, and the results were quantified using Computerized Speech Lab. In the self-report questionnaire, respondents were asked about the subjective difficulty they encountered during the stages of respiration, phonation, articulation, and prosody based on a 5-point Likert scale. Results: First, shimmer, noise to harmonic ratio, and amplitude tremor intensity index in the maximum phonation time task, and the total repeat frequency of /pu/ and /putuku/, and /putuku/DDKsdp in the diadochokinesia task were significantly higher in the moderate/severe group; the total repeat frequency of /tu/ and /ku/ was significantly lower in the moderate/severe group; and the two groups showed no significant difference in the reading task. Second, the moderate/severe group complained of more difficulty in the self-reporting questionnaire. Third, speech evaluation measures and the questionnaire showed a correlation between voice-related diverse complaints and correct articulation and the speech evaluation measures in the mild group, while voice intensity or speech rate were correlated with speech evaluation measures in the moderate/severe group. Conclusion: Speech difficulty indicators in patient groups may differ with Parkinson's disease severity. This implies that self-recognition regarding speech characteristics should be considered in the intervention plan and prognosis establishment.

Keywords: Parkinson's disease, Hypokinetic dysarthria, Instrumental evaluation, Auditoryperceptual evaluation, Self-evaluation scale
파킨슨병(Parkinson's disease, PD)은 대표적인 퇴행성 신경계 질 환으로 알츠하이머형 치매 다음으로 발병률이 높고(Seol, 2008), 우 리나라의 경우 60 세 이상의 노인에서 파킨슨병이 $2.78 \%$ 의 유병률 을 보이는 것으로 보고되었다(Korea Centers for Disease Control and Prevention, 2007). 이 질환은 중뇌에 있는 흑질의 신경세포가 퇴화하면서 도파민 생성이 부족해지고, 이로 인해 기저핵 조절회 로(basal ganglia control circuit)에 신경학적 결함이 발생하면서 (Freed, 2012) 주요 증상인 강직(rigidity), 느린 움직임(bradykinesia), 떨림(tremor), 자세 불안정(posture instability) 등을 보이게 된 다. 이와 같은 사지운동장애는 호흡, 발성, 공명, 조음, 운율 및 말 속 도 등의 말 산출 측면에 부정적인 영향을 주며, 하위체계별 기능저 하 정도에 따라 다양한 말장애가 유발된다. 
우선, 호흡과 발성 측면에서는 흥곽근육의 협응 저하로 호흡량 은 감소하고, 호흡주기는 짧아지며, 호흡근육 운동의 움직임 제한 으로 발화 시 날숨 조절력이 감소한다(Freed, 2012). 이러한 어려움 은 결과적으로 음성의 크기를 감소시키며, 기식성 음성을 초래하게 된다. 또한 성문상부의 기류 방해로 인해 날숨이 비효율적으로 사 용되어(Kim et al., 2011; Sabaté, González, Ruperez, \& Rodríguez, 1996; Vincken et al., 1984) 일관되게 저하된 최대연장발성 지속시 간(maximum phonation time, MPT)을 보인다(Chun et al., 2010; Kim et al., 2011).

특히, 발성 측면에서는 음성의 크기가 감소하는 발성부전(hypophonia)이 관찰된다. 이는 호흡 및 발성기관의 강직으로 성문하압이 저하되거나 후두근의 운동이 원활하지 못할 경우 발생하며(Kim, 2012), 심한 경우에는 발성불능증(aphonia)을 동반하기도 한다. 음 도 조절에서 주요한 역할을 담당하는 반지방패근(cricothyroid muscle)과 성대근(vocal cord muscle)의 강직(stiffness)으로 주파 수 저하가 유발되며(Kang, Kim, Ban, \& Seong, 2009), 성대의 휨 (bowing)으로 음질 관련 파라미터에서 비정상적으로 높은 수치가 나타나거나 저하된 강도를 보인다(Duffy, 2005; Kang et al., 2009; Perez, Ramig, Smith, \& Dromey, 1996). 또한 발성 시 성대 내전이 불완전하여 바람이 새면서 거친 음성이 나타난다(Gerratt, Hanson, \& Berke, 1991; Uziel, Bohe, Cadilhac, \& Passouant, 1975). 발 화 시 발성부전과 기식성 음성이 동반될 경우, 결과적으로 말 명료 도가 저하될 수 있다(Freed, 2012).

조음과 운율 측면은 말 하위체계 중 파킨슨병으로 인한 결함이 가장 두드러지는 것으로 보고된다(Freed, 2012). 조음에서는 조음 기관의 운동 범위제한으로 상대적으로 빠르게 조음되면서 말 뭉침 이 관찰되기도 한다(Freed, 2012; Kim, Yoon, \& Lee, 2015; Ludlow, Bassich, McNeil, Rosenbek, \& Aronson, 1984). 또한 파킨슨병 환자 의 경우는 정상 노화와는 구별되는 말명료도를 보였다(Shim, Park, \& Ko, 2012). 이는 언어학적 단위의 증가에 따른 영향뿐만 아니라 바람이 새는 듯한 쉰 음성, 저하된 음성강도 등의 말 특성에 따른 영향으로 주장되었다(Ramig, Fox, \& Sapir, 2008).

운율 중 말속도와 관련된 선행연구에 의하면 파킨슨병 환자는 일반적으로 빠른 말속도(Freed, 2012)를 보이는 것으로 알려져 있 지만 환자에 따라서 정상군에 비해 느린 반복을 보이는 경우도 있 다(Jung, Cho, Kim, \& Kim, 2011; Kang et al., 2009). 말의 규칙성 측면에서는 불규칙한 음절 반복 양상(Jung et al., 2011)을 보이거나 발화 시 부적절한 쉼(inappropriate silences)이 보고되었는데 이는 시간 조절능력의 손상(Ackermann, Konczak, \& Hertrich, 1997), 운동의 시작 및 멈춤의 어려움(Hirose, 1986; Ko, Kim, Choi, \&
$\mathrm{Kim}, 2010)$, 또는 진행 중인 운동을 억제하는 기능의 감소에 기인 한 것으로 설명되었다(Seiss \& Praamstra, 2004). 파킨슨병 환자군 에서 관찰되는 운율의 단조로움은 호흡과 관련된 근육의 강직에 의해 음성강도의 유연한 조절 실패로 해석하기도 한다(Darley, Aronson, \& Brown, 1969a, 1969b; Kang, Seong, \& Yoon, 2011).

상기와 같이 파킨슨병 환자를 대상으로 한 말 하위체계별 특징 에 대한 연구는 주로 평가자에 의한 객관적(기기적) 및 주관적(청지 각적) 평가에 근거하고 있다(Dykstra, Hakel, \& Adams, 2007; Jeong, 2016; Park, 2013). 이러한 연구를 통해 파킨슨병으로 인한 말특성 을 확인하고 강점과 약점을 파악하는 것은 중재 계획에 있어 매우 중요하다. 그리고 평가를 통해 확인한 객관적인 징후와 더불어 증 상에 대한 환자의 인식 여부는 말장애 개선에 영향을 줄 수 있다. 따라서 중재 계획을 수립할 때 환자의 동기나 장애에 대한 인식 정 도를 함께 확인하는 것은 치료의 효과나 예후를 예측할 수 있게 한 다. 임상가만을 중심으로 시행되고 해석되는 평가결과는 외형적 징후에 초점을 맞춘 평가이기 때문에 한 개인이 장애나 증상에 대 해 느끼는 심리측정적 정도가 결과에 반영되지 못하는 제약을 가 진다. 이러한 한계를 보완하기 위한 노력으로 최근에는 환자 스스로 장애를 인식하는 정도를 설문에 응답하는 방식으로 신체적 기능, 심리사회적 태도, 또는 감정상태를 확인하거나(Aaronson, 1988), 증상이 개인의 삶의 질(quality of life)에 미치는 영향을 반영한 종 합적 평가에 대한 관심이 증가하고 있는 추세이다(Pyo \& Song, 2010). 의사소통 측면에서는 ASHA 의사소통 삶의 질 척도(ASHA Quality of Communication Life Scale, ASHA QCL), 음성장애 측 면에는 음성관련 삶의 질(Voice-Related Quality of Life, V-RQOL), 음성장애지수(Voice Handicap Index, VHI) 등이 대표적으로 사 용되고 있다. 파킨슨병 환자를 대상으로는 말명료도가 삶의 질에 미치는 영향을 살펴본 선행연구(Dykstra et al., 2007; Jeong, 2016; Park, 2013)에서는 말명료도 저하로 인하여 삶의 질이 저하됨을 확 인하였다. 그러나 파킨슨병의 말장애는 말명료도뿐만 아니라 앞서 언급하였듯이 다양한 말하위체계의 결함을 보일 수 있으므로 호 흡, 발성, 조음, 운율 측면에서의 자가인식정도를 다각적으로 확인 할 필요가 있다. 또한 이러한 자가평가결과와 평가자에 의한 측정 치를 비교하여 실제로 관찰되는 징후와 환자가 호소하는 증상과의 관계를 살펴보아야한다.

이에 본 연구는 파킨슨병 환자의 사지운동 중증 정도에 따라 경 도단계(mild stage)와중/고도단계(moderate/severe stage)로 구분한 뒤 평가자 중심의 기기적, 청지각적 평가와 심리측정적 평가에 기반 한 환자 자가평가척도 결과를 비교하여 환자의 주관적 보고가 말 평가에서 지니는 객관적 타당성에 대한 근거를 확인하고자 하였다. 


\section{연구방법}

\section{연구대상}

본 연구는 서울, 인천, 경기, 전라, 경상 지역에 거주하며, 신경과 전문의로부터 파킨슨병으로 진단을 받은 후 항파킨슨 약물을 복 용하고 있는 파킨슨병 환자 40 명을 대상으로 진행되었다. 대상자 선별은 한국형 간이정신상태검사(Korean Version of Mini-Mental State Exam, K-MMSE; Kang, Na, \& Hahn, 1997)를 실시하여 연령과 교육수준에 따른 정상규준(Kang, 2006)에 속하는 자로 제 한하였다. 파킨슨병으로 인해 환자의 $40-50 \%$ 에서 우울증이 나타 난다는 연구결과(Cummings \& Masterman, 1999)에 근거하여 본 연구에서는 우울증 동반 여부를 단축형 노인우울척도(Short form Geriatric Depression Scale, SGDS; Kee, 1996)를 사용하여 확인하 였다. 또한 파킨슨병의 치료법의 하나인 뇌심부자극술이 말음성의 개선여부에 영향을 보였다는 연구결과(Choi, 2012)에 근거하여 이 를 확인하였으며 뇌심부자극술을 시행받은 대상자는 없었다.

환자의 사지운동장애 정도는 수정된 Hoehn-Yahr 척도(modified Hoehn \& Yahr Scale; Goetz et al., 2004)를 사용하였다. Hoehn-Yahr 척도에서 5.0 에 해당하는 대상자는 독립적인 거동 자체가 불가능 하여 평가 참여 자체가 어렵거나 검사 자체를 거부하는 경우가 빈 번하여 1.0 에서 4.0 에 해당하는 대상자만을 대상으로 하였다. 국립 파킨슨재단(National Parkinson Foundation)에 의하면 일반적으 로 Hoehn-Yahr 척도 3.0점부터 자세불안정이 나타나는데 이는 질 환 초기의 경도단계 환자에게서는 흔하게 나타나지 않는 증상으로 보고되어 본 연구에서는 이러한 임상적 증상을 근거로 대상군을 경도(1.0, 1.5, 2.0, 2.5점) 및 중/고도(3.0, 4.0점) 단계의 두 집단으로 구분하였다. 집단 간 연령, 학력, K-MMSE, SGDS, post onset time $(\mathrm{POT})$ 에는 차이가 없었다 $(p>.05)$. 연구대상자에 대한 구체적인 정 보는 Table 1과 같다.

Table 1. Participants' characteristics

\begin{tabular}{lcc}
\hline & $H-Y$ mild $(\mathrm{N}=30)$ & $H-Y$ moderate/severe $(\mathrm{N}=10)$ \\
\hline Age (yr) & $60.83 \pm 7.75$ & $63.00 \pm 7.63$ \\
Education (yr) & $12.40 \pm 3.17$ & $12.60 \pm 2.63$ \\
K-MMSE & $27.90 \pm 1.71$ & $27.90 \pm 1.52$ \\
SGDS & $6.03 \pm 3.64$ & $7.70 \pm 5.44$ \\
POT (yr) & $7.77 \pm 5.04$ & $8.60 \pm 6.31$ \\
H\&Y scale & $1.78 \pm .55$ & $3.70 \pm .48$ \\
\hline
\end{tabular}

Values are presented as mean \pm SD.

$\mathrm{H}-\mathrm{Y}=$ Hoehn \& Yahr scale; K-MMSE = Korean version of Mini-Mental State Examination; SGDS=Short form Geriatric Depression Scale; POT = post onset time.

\section{연구 과제 및 절차}

자가평가척도 제작

본 연구에서는 파킨슨병 환자에서 말과 관련된 호소를 확인하기 위한 자가평가척도를 개발하였다. 설문 문항개발을 위해 먼저 파킨 슨병 환자의 말 하위체계 영역별 특성을 보고한 문헌을 고찰한 뒤 말산출의 하위체계별로 보고된 주요 말특성을 정리하였다. 일반적 으로 파킨슨병 환자들은 말산출기관의 강직으로 호흡, 발성, 조음, 운율 등에서 기능이 두드러지나(Kim, 2012). 공명기능에서는 과다 비성이 $10 \%$ 미만으로 확인된다는 결과(Freed, 2012; Logemann, Fisher, Boshes, \& Blonsky, 1978)에 근거하여 설문항목에서 공명을 제외하고 '호흡/발성, 조음/운율'의 두 가지 하위 범주로 구분하였 다. 그 후, 기존에 발표된 자가말척도 설문을 검토한 뒤 문항을 인용 및 수정하는 방법을 사용하여 1 차에서 18 개의 예비문항을 선정하 였다.

1 차 예비문항에 대한 내용타당도를 확인하기 위하여 말운동장 애와 관련하여 평균 6년 이상의 임상경력을 지닌 언어재활사 7명에 게 문항 구성 및 내용의 적절성을 Likert 척도로 평가하도록 하였 다. 0 점(전혀 적절하지 않다)-4점(매우 적절하다)의 5 점 척도 중 3 점 이상의 항목들에 대해 언어재활사의 의견을 재수렴하여 중첩된 내 용이나 모호한 문항, 어려운 단어를 수정 및 보완하였다. 그 결과, 호흡/발성과 조음/운율 범주에서 각각 6 문항씩 총 12 문항이 선정 되었다.

2 차 예비문항에 대한 내용타당도는 말운동장애와 관련하여 평 균 6년 이상의 임상경력을 지닌 새로운 언어재활사 4 명에게 문항 구성과 내용의 적절성과 관련하여 Likert 척도로 평가하게 하였다. 그 결과, 0-4점의 5점 척도 중 모든 문항이 3점 이상의 타당도를 보 인 문항을 선택하여 최종적으로 Appendix 1의 자가평가척도 설문 지를 완성하였다. 설문지는 Likert 5 점 척도 $(0=$ 전혀 그렇지 않다, $1=$ 그렇지 않다, $2=$ 보통이다, $3=$ 그렇다, $4=$ 매우 그렇다)를 사용해 구성하였고, 호흡/발성 총점, 조음/운율 총점으로 점수를 산정하였 다. 따라서 호흡/발성, 조음/운율 총점은 각각 24점이 가장 높은 점 수이며, 점수가 높을수록 환자 본인이 주관적으로 느끼는 말 어려 움의 정도가 심한 것을 의미한다.

\section{연구절차}

대상자 음성은 소음이 차단된 조용한 방에서 대상자와 연구자가 마주 앉은 상태에서 1:1로 수집되었다. 자료수집에 앞서 대상자에 게 연구 목적과 실시 과제 등에 대해 충분히 설명을 하였고, 참여 동의를 구하였다. 평가 실시 전 대상자를 통해 직접적으로 발병 전 의 말과 언어 사용 능력, 현재의 청력 상태, 파킨슨병을 제외한 기타 
질환 동반 여부를 확인하였다.

평가는 대상자에게 발병 전과 비교하여 발병 후 느끼는 말 불편 함의 정도를 묻는 자가보고 설문식의 자가평가척도를 먼저 실시한 뒤, 평가자가 측정하는 말과제를 시행하였다. 말과제 진행의 구체적 인 절차는 다음과 같았다. 첫째, 검사자는 대상자의 MPT 자료를 수집하기 위해 대상자에게 '숨을 최대한 들이마신 뒤 편안한 상태 에서 중간에 끊지 말고, 최대한 길게 소리 내주세요.'라고 지시하였 다. 둘째, 대상자의 길항반복운동(diadochokinesis, DDK) 능력을 확인하기 위해 대상자에게 '제가 그만 할 때까지 숨을 들이마시고 최대한 빠르고 정확하게, 규칙적으로 5 초 동안 /퍼/, /터/, / 커/, 또는 /퍼터커/를 연속적으로 반복해주세요.'라고 지시하였다. 검사자는 모든 평가 과제에서 대상자의 이해를 돕기 위해 1 회의 시범을 보여 주었고, 대상자는 과제를 각각 3 회씩 수행하였다. 마지막으로 문단 수준에서 대상자의 말특성을 살펴보기 위해 '가을 문단' 읽기를 실 시하였다. 검사자는 대상자에게 글을 소리 내어 읽기 전 문단 글을 1 회 묵독하게 하였다. 그리고 ‘평소에 말씀하실 때처럼 자연스럽고 편안한 목소리로 처음부터 끝까지 읽어주세요.'라고 지시하였고 대 상자는 본 과제를 1 회 수행하였다. 연구의 모든 절차는 한림대학교 생명윤리위원회의 승인을 받았다(No. HIRB-2017-012).

\section{자료수집 도구}

녹음 시, 단일지향형 콘덴서 마이크(ECM-MS907; SONY, Japan)와 휴대용 음성녹음기(PCM-M10; SONY, Japan)를 사용하였 고, 분석 시 GoldWave (version. 5.12)를 사용하여 음성파일을 wav 파일로 변환한 뒤 KayPENTAX Computerized Speech Lab 프로그 램(MODEL 4150B)을 사용하여 분석하였다. 선행연구(Narayana et al., 2010)에 근거하여 말 자료 녹음을 위하여 마이크는 대상자의 입에서 $30 \mathrm{~cm}$ 떨어진 거리에, $20^{\circ}$ 각도를 유지하도록 위치시켰다.

\section{분석방법}

MPT 분석

KayPENTAX CSL을 사용하여 MPT, 주파수변동률(jitter percent, Jitt), 진폭변동률(shimmer percent, Shim), 소음대배음 비율 (noise to harmonic ratio, NHR), 약한(가냘픈) 음성 지수(soft phonation index, SPI), 기본주파수의 떨림 강도 지수 ( $\mathrm{F}_{0}$-tremor intensity index, FTRI), 진폭의 떨림 강도 지수(amplitude tremor intensity index, ATRI), 강도(intensity), 기본주파수(fundamental frequency, $\left.\mathrm{F}_{0}\right)$ 를 분석하였다.

환자가 3 회 연장 발성한 모음 중에서 '가장 우수한 수행 반응(best performance) (Kim et al., 2004)'을 보인 자료를 선택하였고, MPT
는 음성강도가 시작된 부분부터 끊어지지 않고 끝나는 지점까지를 측량자(cursor)로 지정하여 시간을 확인하였다. 나머지 음성 관련 파라미터들은 2 초 동안의 안정구간을 분리해 측정하였다.

\section{$\mathrm{DDK}$ 분석}

KayPENTAX CSL의 Motor Speech Profile (MSP)을 사용하였 으며, 환자의 3 회 수행 중에서 '가장 우수한 수행 반응'을 선택하여 그 중에서 5 초의 반복 구간을 분석하였다. 환자의 말 반복 횟수, 속 도, 규칙성 특성을 확인하기 위하여 교대운동속도(alterative motor rate, AMR)와 일련운동속도(sequence motor rate, $\mathrm{SMR}$ )의 총 반 복 횟수(total repeat frequency, TRF)와 적절하게 반복한 횟수(appropriate repeat frequency, ARF), 부적절하게 반복한 횟수(inappropriate repeat frequency, IRF), 평균 DDK 속도(average DDK rate, DDKavr), $\mathrm{DDK}$ 구간의 표준편차(standard deviation of $\mathrm{DDK}$ period, DDKsdp)를 선택하였다.

말뭉침 확인을 위해 $\mathrm{AMR}$ 을 분석하였는데 $\mathrm{SMR}$ 은 말의 순차성 (sequencing)을, AMR은 속도(rate)와 규칙성(regularity)을 민감하 게 반영한다는 선행연구(Duffy, 2005)에 근거하여 본 연구는 AMR 을 선택 분석하였다. 분석 시 광대역 스펙트로그램(wide-band spectrogram)을 활용하여 AMR의 폐쇄구간(closure duration), 터짐 (burst), 기식구간(aspiration), 모음 음형대 구간(Shin, 2011)에 근거 한 분절(segmentation)의 경계를 근거로 하여 분석하였다.

반응시간(response time)은 검사자의 지시가 끝난 부분부터 대 상자가 과제를 시작한 부분까지의 구간을 음성파일 파형에서 선택 하여 산정하였다.

\section{읽기 분석}

환자군의 조음정확도(articulation accuracy)를 살펴보기 위해 대상자가 읽은 문단의 발화를 전사한 뒤 대상자가 바르게 조음한 음소의 수를 목표음소의 수로 나눈 뒤 100 을 곱하여 계산하였다.

문단읽기 시 말의 속도와 쉼 특성을 살펴보았는데, 이는 KayPENTAX CSL 프로그램에 있는 Main Program을 이용하였다. 측 정 파라미터로는 전체 속도(total speech, TS), 조음 속도(articulatory speech, AS), 적절한 심 빈도(appropriate pause frequency, APF), 부적절한 쉼 빈도(inappropriate pause frequency, IPF), 부적절하게 삽입된 소리(inappropriate sound, IS), 비유창 반복 횟수(repeat frequency, RF)를 선택하였다. 말속도 및 쉼 특성에서 사용된 파라 미터의 일부는 Kim과 $\operatorname{Sim}$ (2001)의 연구를 참고하였다(Table 2). 
Hyeon Ah Kim, et al. • Self-report on Speech Characteristics in Parkinson's Disease

Table 2. Definition of speech rate related parameters

\begin{tabular}{ll}
\hline & \multicolumn{1}{c}{ Definition } \\
\hline $\begin{array}{l}\text { Total speed } \\
\text { Articulatory speed }\end{array}$ & $\begin{array}{c}\text { The time to read a sentence expressed in syllables per second, including pauses. } \\
\text { syllables and words ("disfluency") is observed here. }\end{array}$ \\
Pause frequency & The number of pauses within sentences. A pause is a section of at least $150 \mathrm{~ms}$ ( 0.15 seconds) where utterances are not connected. \\
\hline
\end{tabular}

Table 3. MPT task value according to by group

\begin{tabular}{lccc}
\hline & H-Y mild & H-Y moderate/severe & $F$ \\
\hline MPT duration & $14.13 \pm 7.17$ & $11.54 \pm 7.28$ & 2.860 \\
Intensity (dB) & $64.00 \pm 7.90$ & $57.26 \pm 9.31$ & 3.359 \\
Fo $_{0}(\mathrm{~Hz})$ & $176.62 \pm 35.09$ & $155.22 \pm 43.27$ & .002 \\
Jitter & $2.43 \pm 2.14$ & $2.41 \pm 1.96$ & 1.919 \\
Shimmer & $7.33 \pm 5.37$ & $8.35 \pm 4.23$ & $11.418^{* *}$ \\
NHR & $.17 \pm .06$ & $.20 \pm .13$ & $7.857^{* *}$ \\
SPI & $13.22 \pm 7.19$ & $22.74 \pm 10.54$ & .006 \\
FTRI & $.62 \pm .73$ & $.96 \pm .80$ & 2.272 \\
ATRI & $5.63 \pm 3.90$ & $9.23 \pm 5.55$ & $4.203^{*}$ \\
\hline
\end{tabular}

Values are presented as mean $\pm \mathrm{SD}$.

$\mathrm{MPT}=$ maximum phonation time; NHR= noise to harmonic ratio; $\mathrm{SPI}=$ soft phonation index; $\mathrm{FTRI}=\mathrm{F}_{0}$-tremor intensity index; $\mathrm{ATRl}=$ amplitude tremor intensity index. ${ }^{*} p<.05,{ }^{* *} p<.01$.

\section{연구결과}

\section{사지운동 중증에 따른 집단 간 차이}

평가자의 말과제 측정치 비교

사지운동증상에 따른 평가자의 말과제 측정결과를 비교하기 위 해서 평가에 영향을 줄 수 있는 SGDS 점수를 통제한 공분산분석 (ANCOVA)을 실시하였다. MPT 과제에서는 Shim ( $p=.002), \mathrm{NHR}$ ( $p=.008)$, ATRI ( $p=.047)$ 에서 중/고도집단이 경도집단보다 유의 하게 높은수치를 보였다(Table 3).

$\mathrm{DDK}$ 과제에서 /퍼/의 총 반복 횟수 $(p=.009)$, /퍼터커/의 총 반복 횟수 $(p=.004)$, /퍼터커/의 DDKsdp $(p=.017)$ 는 중/고도집단이 경 도집단보다 통계적으로 유의미하게 높았다. /터/의 총 반복 횟수 ( $p=.013)$, /커/의 총 반복 횟수( $p=.047)$, /퍼/의 적절한 반복 횟수, /퍼터커/의 적절 반복 횟수 $(p=.006)$ 는 중/고도집단이 경도집단보 다 유의하게 낮았다(Table 4). 읽기 과제에서는 모든 파라미터에서 집단 간에 유의미한 차이가 없었다(Table 5).

\section{환자의 자가평가척도 비교}

사지운동증상에 따른 환자의 자가평가결과를 비교하기 위해서 평가에 영향을 줄 수 있는 SGDS 점수를 통제한 공분산분석(AN-
Table 4. DDK task value according to group

\begin{tabular}{|c|c|c|c|}
\hline & $\mathrm{H}-\mathrm{Y}$ mild & $\mathrm{H}-\mathrm{Y}$ moderate/severe & $F$ \\
\hline \multicolumn{4}{|l|}{$/ \mathrm{pu} /$} \\
\hline TRF & $23.23 \pm 6.22$ & $24.00 \pm 9.42$ & $7.512^{* *}$ \\
\hline ARF & $21.83 \pm 6.97$ & $17.80 \pm 11.09$ & $6.934^{*}$ \\
\hline IRF & $1.40 \pm 2.24$ & $2.70 \pm 3.34$ & .127 \\
\hline DDKavr & $5.21 \pm 2.55$ & $7.00 \pm 6.11$ & .103 \\
\hline DDKsdp & $117.73 \pm 193.00$ & $130.03 \pm 196.41$ & .089 \\
\hline $\mathrm{RT}$ (sec) & $.46 \pm .36$ & $.51 \pm .18$ & 4.012 \\
\hline \multicolumn{4}{|l|}{$/ \mathrm{tu} /$} \\
\hline TRF & $23.30 \pm 5.53$ & $22.40 \pm 6.36$ & $6.870^{*}$ \\
\hline ARF & $21.57 \pm 6.13$ & $21.00 \pm 8.07$ & 3.174 \\
\hline IRF & $1.73 \pm 4.02$ & $1.40 \pm 3.41$ & .405 \\
\hline DDKavr & $4.58 \pm 2.22$ & $3.59 \pm 1.80$ & .432 \\
\hline DDKsdp & $138.86 \pm 255.24$ & $124.46 \pm 191.39$ & .955 \\
\hline RT (sec) & $.43 \pm .31$ & $.40 \pm .17$ & .466 \\
\hline \multicolumn{4}{|l|}{ /ku/ } \\
\hline TRF & $23.53 \pm 6.52$ & $21.90 \pm 6.69$ & $4.236^{*}$ \\
\hline ARF & $21.37 \pm 6.78$ & $14.60 \pm 8.73$ & 2.730 \\
\hline IRF & $2.17 \pm 4.25$ & $7.30 \pm 9.20$ & .041 \\
\hline DDKavr & $3.55 \pm 1.67$ & $3.05 \pm 2.10$ & .035 \\
\hline DDKsdp & $141.46 \pm 135.16$ & $126.02 \pm 126.00$ & 2.947 \\
\hline $\mathrm{RT}$ (sec) & $.38 \pm .19$ & $.45 \pm .13$ & .393 \\
\hline \multicolumn{4}{|l|}{ /putuku/ } \\
\hline TRF & $8.40 \pm 2.25$ & $8.50 \pm 3.06$ & $9.227^{* *}$ \\
\hline ARF & $7.63 \pm 2.85$ & $5.90 \pm 3.11$ & $8.403^{* *}$ \\
\hline IRF & $.77 \pm 2.33$ & $2.60 \pm 4.48$ & .089 \\
\hline DDKavr & $4.66 \pm 1.79$ & $3.97 \pm 1.77$ & .841 \\
\hline DDKsdp & $77.51 \pm 60.31$ & $84.95 \pm 56.21$ & $6.308^{*}$ \\
\hline RT (sec) & $.34 \pm .15$ & $.35 \pm .19$ & 1.425 \\
\hline
\end{tabular}

Values are presented as mean $\pm \mathrm{SD}$.

$\mathrm{TRF}=$ total repeat frequency; $\mathrm{ARF}=$ appropriate repeat frequency; IRF= inappropriate repeat frequency; $\mathrm{RT}=$ response time.

${ }^{*} p<.05,{ }^{* *} p<.01$.

COVA)을 실시하였다. 그 결과, 호흡/발성 $(p<.001)$ 및 조음/운율 $(p=.002)$ 모두에서 중/고도집단이 경도집단에 비해 수치가 유의미 하게 높았다(Table 6).

\section{말과제 측정치와 자가평가척도 간 상관관계}

파킨슨병 환자의 주관적 말 산출능력 저하에 영향을 미치는 말 
Table 5. Reading task value according to group

\begin{tabular}{lccr}
\hline & H-Y mild & H-Y moderate/severe & $F$ \\
\hline AA & $98.37 \pm 2.79$ & $95.57 \pm 6.94$ & 3.257 \\
TS & $.22 \pm .05$ & $.23 \pm .04$ & 1.153 \\
AS & $.18 \pm .04$ & $.17 \pm .04$ & .057 \\
APF & $29.30 \pm 12.73$ & $36.60 \pm 9.90$ & 1.718 \\
IPF & $2.87 \pm 2.62$ & $3.60 \pm 2.84$ & 2.984 \\
IS & $2.10 \pm 3.30$ & $2.60 \pm 3.86$ & 1.581 \\
RF & $3.83 \pm 4.12$ & $2.70 \pm 1.42$ & .848 \\
\hline
\end{tabular}

Values are presented as mean $\pm S D$.

$\mathrm{AA}=$ articulation accuracy; $\mathrm{TS}=$ total speed; $\mathrm{AS}=$ articulatory speed; $\mathrm{APF}=$ appropriate pause frequency; IPF= inappropriate pause frequency; $I S$ = inappropriate sound; $R F=$ repeat frequency.

Table 6. Self-reported score according to group

\begin{tabular}{lccc}
\hline & $H-Y$ mild & $H-Y$ moderate/severe & $F$ \\
\hline R/P score & $12.73 \pm 5.11$ & $16.30 \pm 3.43$ & $17.703^{* * *}$ \\
A/P score & $12.93 \pm 5.45$ & $16.60 \pm 3.72$ & $11.123^{* *}$ \\
\hline
\end{tabular}

Values are presented as mean \pm SD.

$\mathrm{R} / \mathrm{P}$ score $=$ respiration/phonation score; $\mathrm{A} / \mathrm{P}$ score $=$ articulation/prosody score . ${ }^{* *} p<.01,{ }^{* * *} p<.001$.

하위체계별 파라미터를 확인하기 위해 전체, 경도와 중/고도 파킨 슨병 환자로 나누어 말과제에서 측정된 말 파라미터와 환자의 자가 평가척도 간의 상관관계를 살펴보았다. 자가평가척도의 호흡/발성 영역에 해당하는 수치는 기존 문헌(Kim, 2012; Ko, 2015)에서 호흡 의 능력 및 음성 기능과 관련된 정보를 제공하는 지표로 사용되어 온 MPT, APF, IPF, intensity, Jitt, Shim, NHR, SPI, FTRI, ATRI, Fo 와의 상관성을 확인하였다. 자가평가척도의 조음/운율 영역에 해당 하는 수치는 기존 문헌(Ko et al., 2010; Jung et al., 2011; Ko, 2015)에 서 조음능력, 운율과 관련해 속도, 규칙성, 쉼 등의 정보를 제공하는 지표로 사용된 조음정확도, $\mathrm{AMR}, \mathrm{SMR}$ 의 TRF, $\mathrm{ARF}, \mathrm{TRF}, \mathrm{DD}-$ Kavr, DDKsdp, RT, 그리고 IS, RF, IPF와의 상관성을 확인하였다.

\section{전체 집단의 과제 간 상관관계}

\section{호흡/발성}

환자 중심의 자가평가척도와 평가자 중심의 평가 중 호흡/발성 과 관련된 파라미터에 대한 상관관계를 분석하였다. 1 번 문항('말 할 때 숨이차서 숨을 자주 쉰다')은 모음연장발성의 intensity, Shim, NHR과 상관관계를 보였다. 2번 문항('전반적인 목소리의 크기가 작다')은 intensity와 상관성이 있었다. 3번 문항('말을 하면 목소리 크기가 점점 작아진다')은 intensity, Shim, NHR, FTRI와 통계적으 로 유의한 상관관계를 보였다. 4 번 문항('바람이 새며 쉰 듯한 목소 리가 난다')은 Shim, NHR, FTRI와 상관을 보였다. 5번 문항('목소
Table 7. Correlation between patient-centered evaluation and evaluator-centric evaluation regarding respiration and phonation

\begin{tabular}{lcccccc}
\hline & 1 & 2 & 3 & 4 & 5 & 6 \\
\hline Intensity & $-.380^{*}$ & $-.364^{*}$ & $-.403^{* *}$ & -.191 & $-.411^{* *}$ & $-.367^{*}$ \\
Shimmer & $.402^{*}$ & .270 & $.364^{*}$ & $.478^{* *}$ & $.431^{* *}$ & $.377^{*}$ \\
NHR & $.383^{*}$ & .262 & $.353^{*}$ & $.388^{*}$ & .302 & .307 \\
FTRI & .302 & .262 & $.347^{*}$ & $.322^{*}$ & $.366^{*}$ & .297 \\
\hline
\end{tabular}

$\mathrm{NHR}=$ noise to harmonic ratio; FTRI = Fo-tremor intensity index. ${ }^{*} p<.05,{ }^{* *} p<.01$.

Table 8. Correlation between patient-centered evaluation and evaluator-centric evaluation regarding articulation and prosody

\begin{tabular}{lcccccc}
\hline & 7 & 8 & 9 & 10 & 11 & 12 \\
\hline /putuku/ DDKavr & $-.436^{* *}$ & $-.315^{*}$ & -.305 & -.192 & -.159 & -.183 \\
/putuku/ DDKsdp & $.386^{*}$ & .170 & .304 & .281 & .233 & $.332^{*}$ \\
/putuku/ ARF & $-.432^{* *}$ & -.108 & -.284 & -.053 & -.149 & -.232 \\
TS & $.313^{*}$ & -.069 & .086 & -.154 & .051 & .016 \\
/pu/ ARF & $-.332^{*}$ & -.114 & -.215 & -.029 & -.072 & -.223 \\
/ku/ ARF & $-.439^{* *}$ & -.156 & $-.333^{*}$ & -.050 & -.124 & -.265 \\
IS & .239 & $.453^{* *}$ & .216 & -.124 & .075 & .179 \\
\hline
\end{tabular}

DDK = diadochokinesis; DDKavr = average DDK rate; DDKsdp = standard deviation of DDK period; $A R F=$ appropriate repeat frequency; $T S=$ total speed; IS= inappropriate sound.

${ }^{*} p<.05,{ }^{* *} p<.01$.

리가 떨린다')은 intensity, Shim, FTRI와 유의미한 상관관계를 보 였다. 6번 문항('목소리 크기와 높이가 변화 없이 단조롭다')은 intensity, Shim과 상관관계를 나타냈다(Table 7).

\section{조음/운율}

7번 문항('발음이 부정확하다')은 /퍼터커/의 DDKavr, DDKsdp, 반복 횟수, /퍼/의 반복 횟수, / 커/의 반복 횟수, 그리고 문단읽기의 전체속도와 유의미한 상관관계를 보였다. 8번 문항('말속도가 달라 겼다')은/퍼터커/의 DDKavr, 문단읽기 시 부적절하게 삽입된 소리 와 상관이 있었다. 9번 문항('말이 웅얼거리듯이 뭉쳐서 나온다')은 /커/의 반복 횟수와 유의한 상관관계가 나타났다. 12 번 문항('말이 중간에 끊긴다')은 /퍼터커/의 DDKsdp와 상관관계를 보였다. 10 번 ('막히면서 말이 시작된다')과 11번('더듬는 것처럼 말을 반복한다') 문항에서는 자가평가척도와 말과제 파라미터 간에 통계적으로 유 의미한 상관 관계가 확인되지 않았다(Table 8).

\section{경도집단의 과제 간 상관관계}

\section{호흡/발성}

1 번 문항('말할 때 숨이 차서 숨을 자주 쉰다')은 NHR과 상관관 계를 보였다. 2 번 문항('전반적인 목소리의 크기가 작다')은 intensi- 
Hyeon Ah Kim, et al. • Self-report on Speech Characteristics in Parkinson's Disease

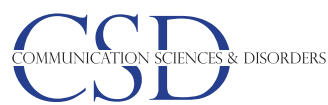

Table 9. Correlation between patient-centered evaluation and evaluator-centric evaluation of mild group regarding respiration and phonation

\begin{tabular}{lcccccc}
\hline & 1 & 2 & 3 & 4 & 5 & 6 \\
\hline Intensity & -.282 & $-.362^{*}$ & -.290 & -.216 & -.233 & -.346 \\
Shimmer & .343 & .345 & $.412^{*}$ & $.469^{* *}$ & $.467^{* *}$ & $.432^{*}$ \\
NHR & $.412^{*}$ & .333 & $.415^{*}$ & $.448^{*}$ & $.417^{*}$ & $.365^{*}$ \\
FTRI & .229 & $.418^{*}$ & $.489^{* *}$ & .339 & .351 & .440 \\
\hline
\end{tabular}

$\mathrm{NHR}=$ noise to harmonic ratio; FTRI = Fo-tremor intensity index. ${ }^{*} p<.05,{ }^{* *} p<.01$.

Table 10. Correlation between patient-centered evaluation and evaluator-centric evaluation of mild group regarding articulation and prosody

\begin{tabular}{lcccccc}
\hline & 7 & 8 & 9 & 10 & 11 & 12 \\
\hline AA & $-.369^{*}$ & -.199 & -.298 & -.299 & -.275 & -.287 \\
/pu/ DDKavr & $-.568^{* *}$ & -.336 & $-.438^{*}$ & -.346 & -.286 & -.189 \\
/tu/ DDKsdp & $.369^{*}$ & .313 & .319 & .263 & .199 & .179 \\
/ku/ DDKsdp & $.375^{*}$ & .193 & .181 & .132 & .207 & .248 \\
/putuku/ DDKavr & $-.449^{*}$ & -.346 & -.286 & -.239 & -.144 & -.156 \\
/putuku/ DDKsdp & $.409^{*}$ & .170 & .356 & $.451^{*}$ & $.373^{*}$ & $.369^{*}$ \\
/ku/ ARF & $-.413^{*}$ & .034 & -.234 & -.123 & -.194 & -.172 \\
IS & .209 & $.477^{* *}$ & .152 & -.043 & .008 & .181 \\
\hline
\end{tabular}

$\mathrm{AA}=$ articulation accuracy; $\mathrm{DDK}=$ diadochokinesis; $\mathrm{DDKavr}=$ average DDK rate; $D D K s d p=$ standard deviation of DDK period; $A R F=$ appropriate repeat frequency; IS = inappropriate sound. ${ }^{*} p<.05,{ }^{* *} p<.01$.

ty, FTRI와 상관을 보였다. 3번 문항('말을 하면 목소리 크기가 점점 작아진다')은 Shim, NHR, FTRI와 유의미한 상관관계를 보였다. 4 번 문항('바람이 새며 쉰 듯한 목소리가 난다')은 Shim, NHR과 상 관이 있었다. 5번 문항('목소리가 떨린다')은 Shim, NHR과 유의한 상관관계를 보였다. 6번 문항('목소리 크기와 높이가 변화 없이 단조 롭다')은 Shim, NHR과 통계적으로 유의한 상관을 보였다(Table 9).

조음/운율

7번 문항('발음이 부정확하다')은 문단읽기 중 조음정확도, 길항 반복운동 중 /퍼/의 DDKavr, /터/의 DDKsdp, /커/의 DDKsdp, /퍼터커/의 DDKavr, /퍼터커/의 DDKsdp, /커/의 반복 횟수와 상관 관계를 보였다. 8 번 문항('말속도가 달라졌다')은 문단읽기 시 부적 절하게 삽입된 소리와 상관이 있었다. 9번 문항('말이 웅얼거리듯 이 뭉쳐서 나온다')은 /퍼/의 DDKavr와 유의미한 상관관계를 보였 다. 10 번('막히면서 말이 시작된다'), 11 번('더듬는 것처럼 말을 반복 한다'), 12 번('말이 중간에 끊긴다') 문항은 /퍼터커/의 DDKsdp와 통계적으로 유의한 상관관계를 보였다(Table 10).
Table 11. Correlation between patient-centered evaluation and evaluator-centric evaluation of moderate/severe group regarding respiration and phonation

\begin{tabular}{lcccccc}
\hline & 1 & 2 & 3 & 4 & 5 & 6 \\
\hline Intensity & .546 & -.215 & $-.644^{*}$ & .327 & $-.769^{* *}$ & -.281 \\
\hline${ }^{*} p<.05,{ }^{* *} p<.01$. & & & & &
\end{tabular}

Table 12. Correlation between patient-centered evaluation and evaluator-centric evaluation of moderate/severe group regarding articulation and prosody

\begin{tabular}{lcccccc}
\hline & 7 & 8 & 9 & 10 & 11 & 12 \\
\hline /ku/ IRF & -.036 & .018 & .054 & $-.655^{*}$ & $-.647^{*}$ & -.179 \\
/putuku/ IRF & .000 & -.238 & -.037 & .534 & -.375 & $-.659^{*}$ \\
/ku/ DDKsdp & -.453 & $-.656^{*}$ & -.485 & -.074 & -.250 & $-.748^{*}$ \\
/pu/ ARF & -.556 & $-.654^{*}$ & -.406 & .126 & .075 & -.608 \\
\hline
\end{tabular}

$\mathrm{IRF}=$ inappropriate repeat frequency; DDKsdp = standard deviation of diadochokinesis period; $A R F=$ appropriate repeat frequency.

${ }^{*} p<.05$.

\section{중/고도집단의 과제 간 상관관계}

호흡/발성

3 번 문항('말을 하면 목소리 크기가 점점 작아진다')과 5 번 문항 ('목소리가 떨린다')은 intensity와 상관관계를 보였다. 자가평가척 도 $1,2,4,6$ 번 문항과 말과제 파라미터 간에는 통계적으로 유의미 한 상관관계가 확인되지 않았다(Table 11).

조음/운율

8 번 문항('말속도가 달라졌다')은 /커/의 DDKsdp, /퍼/의 반복 횟수와 상관관계를 보였다. 10 번('막히면서 말이 시작된다'), 11 번 ('더듬는 것처럼 말을 반복한다') 문항은/커/의 부적절한 반복 횟수 와 유의한 상관관계를 보였다. 12 번 문항('말이 중간에 끊긴다')은 /퍼터커/의 부적절한 반복 횟수, /커/의 DDKsdp와 상관이 있었다 7 번, 9번 자가평가척도 문항과 말과제 파라미터 간에는 통계적으로 유의미한 상관이 확인되지 않았다(Table 12).

\section{논의 및 결론}

본 연구는 파킨슨병 환자를 사지증상 중증에 따라 경도와 중/고 도집단으로 구분한 뒤 집단에 따른 말 수행력을 평가자 측정치와 환자 보고의 자가평가척도에 근거하여 그 결과를 비교하였다. 그리 고 환자와 평가자 측정치 간의 상관관계를 확인하였다.

먼저, 경도 및 중/고도집단에 따른 MPT 과제의 수행력을 비교한 결과, /아/ 연장발성의 MPT duration, intensity, $\mathrm{F}_{0}$, Jitt, SPI, FTRI는 집단 간에 통계적으로 유의미한 차이를 보이지 않았으나 Shim, 
$\mathrm{NHR}, \mathrm{ATRI}$ 는 중/고도집단이 경도집단에 비해 통계적으로 유의하 게 높은 수치를 보였다. 여기서 Shim은 진폭의 변이를, ATRI는 진 폭의 떨림을 의미하는데 이러한 결과는 호흡의 길이나 주파수와 관련한 변동성은 사지운동장애가 저하되는 것과 관련이 없지만 진 폭과 관련된 측정치들은 좀 더 사지운동장애와 관련이 있음을 시 사한다. 파킨슨병은 병이 진행됨에 따라 근육의 강직이 발성 수준 에 점차 많은 영향을 미쳐 음성단계에 문제를 초래한다고 알려져 있다(Hauser, Lyons, Pahwa, \& Zesiewicz, 2003; Ho, Song, \& Chung, 2016). 따라서 중/고도집단에서 Shim과 ATRI의 비정상적 수치는 파킨슨병이 진행되면서 성대근육의 강직으로 인한 성대 휨(vocal fold bowing)에 기인한 것으로 해석될 수 있다(Boutsen, Duffy, \& Aronson, 1998; Duffy, 2005; Ludlow et al., 1984; Kang et al., 2009). $\mathrm{NHR}$ 은 소음대배음의 비율을 의미하는데 성대 휨 등으로 인해 불 완전한 성문폐쇄가 동반되면서 불완전한 난기류의 증가에 따른 결 과로 보여진다(Sewall, Jiang, \& Ford, 2006).

$\mathrm{DDK}$ 의 집단 간 수행력을 비교한 결과, /퍼/의 총 반복 횟수에서 중/고도집단이 경도집단보다 많은 반복 횟수를 보였다. 이는 중/고 도집단에서 경도집단보다 진행된 기저핵의 손상으로 말 산출 시 말 의 타이밍 조절에 어려움이 초래되어 조음의 속도가 부적절하게 빨 라진 것으로 설명될 수 있다(Kim, Lee, Kim, \& Lee, 2003). 그러나 중/고도집단에서 많은 반복 횟수를 보인 /퍼/와 대조적으로 적은 수의 반복을 보인 /터/, /커/와 관련해서는 파킨슨병 중증에 따른 비 교연구는 아니지만 파킨슨병 환자 집단이 /터/, /커/에서 정상 노인 집단보다 느린 수행력을 보인 연구(Kang et al., 2009)에서 그 근거 를 찾을 수 있다. 파킨슨병은 혀 부위 중 후반부를 사용하는 조음 을 산출할수록 운동성이 특히 느리다고 보고되었다(Yunusova, Weismer, Westbury, \& Lindstrom, 2008). 이를 음향음성학적 측면 에서 살펴보면, /퍼/에 비해/커/와 같은 후설음은 성도(vocal tract) 에서 조음자(혀)와 조음기(연구개)의 막음(valving)이 발생하는 부 분부터 성문까지의 공간이 상대적으로 좁아진다. 따라서, 성문상 압이 증가하게 되는데 이는 성대진동 시작시간(voice onset time)을 길어지게 하여(Choi, Choi, \& Lee, 2015) 결과적으로 설배(dorsum of tongue) 부분의 조음동작을 저하시킬 수 있다(Kim, Ko, Shin, Hong, \& Seo, 1997). /퍼터커/의 반복 횟수와 관련해서는 총 반복 횟 수에서 중/고도집단이 경도집단보다 많은 횟수를 반복하였다. 이 는 파킨슨병 '중/고도' 환자들의 가속보행과 같이 반복적 운동이 이루어지는 상황에서 운동저하와 강직 등으로 인하여 운동의 범위 가 점차적으로 작아지고 제한적일 때 가속화되어 나타나는 현상으 로 설명될 수 있다(Duffy, 2005; Moreau et al., 2007). 그러나 양적 인 측면에서의 총 반복 횟수는 중/고도집단에서 더 많았지만 질적
인 측면에서 적절하게 반복한 횟수는 더 적었다. 중/고도집단에서 / 퍼터커/의 반복과제 수행 양상을 살펴보면, '조음점에 미치지 못함 (undershooting)'현상으로 완전히 조음점에 접촉하지 않은 상태에 서 다음 조음 동작을 위해 조음기관을 빠르게 움직이면서 발음하 여 적절한 반복 횟수가 감소된 것으로 해석될 수 있다. 또한 조음기 관의 운동저하와 더불어 성대와의 불협응으로 인하여 말뭉침이 발 생(Kim et al., 2015; Ludlow et al., 1984)하기도 하였는데 앞서 관찰 된 발성단계의 결함이 영향을 주었을 가능성도 배제할 수 없다. /퍼 터커/ 규칙성의 표준편차를 의미하는 DDKsdp에서 중/고도집단이 경도집단보다 높게 나타난 결과 또한 동일한 맥락에서 설명될 수 있 는데, 이는 고유의 진동기제(intrinsic oscillation mechanism)가 비 정상적으로 작동하는 것과 같이 중추신경계의 억제기능장애로 인 하여 점차 빨라지는 편차의 정도가 중/고도집단에서 더 커진 것으 로 보여진다(Hirose, 1986).

문단읽기 과제에서는 모든 측정치에서 집단 간 차이가 관찰되지 않았다. 이는 신체운동과 말운동을 관여하는 대뇌피질 및 피질하 구조가 동일하다는 선행연구(Riecker, Kassubek, Gröschel, Grodd, \& Ackermann, 2006), 신체의 운동 기능이 회복될수록 말 산출의 능력이 개선된다는 선행연구(Barlow, Iacono, Paseman, Biswas, \& D’Antonio, 1998; Theodoros, Ward, Murdoch, Silburn, \& Lethlean, 2000)와 일치하지 않는 결과이다. 그러나 사지운동 기능이 말 산출 운동 기능과 서로 구분되는, 즉 독립적인 신경회로의 통제 가능성 이 있다는 주장(Agid, 1998; Alexander, Crutcher, DeLong, 1991; Bonnet, Loris, Saint-Hilaire, Lhermitte, \& Agid, 1987; Dromey, Kumar, Lang, \& Lozano, 2000; Gentil, Tournier, Pollak, \& Benabid, 1999; Kompoliti, Wang, Goetz, Leurgans, \& Raman, 2000)에 따르면 광범위한 의미에서 말운동이 신체운동의 일부이기는 하지 만 말 산출의 운동은 신체적 운동보다 복잡하고 세밀하며 나아가 고차원적인 기능을 더 필요로 하는 움직임이기 때문일 수 있다(Kim et al., 2012). 집단 간 차이가 관찰되지 않았던 또 다른 가능성으로 과제의 특성을 고려할 필요성이 있다. $\mathrm{MPT}$ 나 $\mathrm{DDK}$ 과제는 말운동 에 보다 초점을 맞춘 과제임에 비하여 문단읽기 과제는 말운동과 더불어 단어 문맥이나 구문처리 등의 언어적 처리능력이 요구되므로 말운동 이외의 기타 능력이 영향을 주었을 가능성이 있겠다(Yoon et al., 2017). 이러한 결과는 파킨슨병 환자가 말 산출 시 전체속도 와 조음속도가 감소하고(Martínez-Sánchez et al., 2016), 쉼 길이 및 빈도, 특히 부적절한 쉼 빈도가 많음에도 불구하고(Ajwani \& Chand-Mall, 2017; Hammen \& Yorkston, 1996) 읽기과제에서는 환자의 중증도와 말 파라미터 간에 유의미한 상관이 없었다(Martínez-Sánchez et al., 2016)는 선행연구와 맥락을 같이 한다. 이러한 
결과는 문단읽기가 MPT와 DDK 과제보다 문맥적으로 큰 단위로 써 호흡, 발성, 조음, 운율의 전반적 말 하위체계 능력을 평가할 수 있는 장점이 있지만, 언어적인 처리과정의 영향을 배제할 수 없다 는 제한점을 시사한다. 따라서 파킨슨병과 더불어 인지능력의 변화 가 수반될 수 있는 여러 신경학적 운동질환의 말운동 능력 평가에 서는 언어적 처리능력이 최소한으로 요구되면서 말운동 능력을 확 인할 수 있는 말과제의 타당성에 대한 고려가 필요하겠다.

그 다음으로, 집단에 따른 자가평가척도 결과를 살펴본 결과, 호 흡/발성과 조음/운율 측면 모두에서 중/고도집단이 경도집단보다 어려움을 호소하는 정도가 심하였다. 문항 중에서는 4 번 문항인 '특히 바람이 새며 쉰 듯한 목소리가 난다'에서 두 집단 간의 차이가 가장 두드러졌다. 이러한 이유는 파킨슨병의 말장애 특성에서 가장 두드러지는 음성 특성, 즉 쉰 음성(hoarseness), 기식 음성(breathiness), 거친 음성(roughness) 등이 환자의 $89 \%$ 에서 관찰된다는 것 과 일맥상통하는 결과로 보여진다(Duffy, 2005).

마지막으로 환자의 자가평가척도 결과와 말과제를 통한 평가자 측정치 간의 상관성을 살펴보았다. 전체 집단을 대상으로 하였을 때, 호흡/발성 측면에서 전반적으로 감소한 음성 크기와 관련된 2 번 문항을 제외한 모든 문항은 Shim과 정적 상관을 나타냈다. 기식 음성과 쉰 음성과 관련된 4 번 문항을 제외한 모든 문항은 intensity 와 부적 상관을 나타냈다. 또한 NHR은 말할 때 숨이 차서 호흡을 자주 한다는 1 번 문항과 말을 할수록 음성 강도가 감소한다는 3 번 문항, 기식성 음성 및 쉰 음성과 관련한 4 번 문항과 FTRI는 말을 할 수록 감소하는 음성크기와 관련한 3 번 문항과 기식음성 및 쉰 음성 과 관련한 4 번 문항, 음성떨림과 관련한 5 번 문항과도 높은 정적 상 관성을 보였다. 이러한 결과는 말 하위체계 중 호흡/발성 시 목소리 의 강도와 강도의 변이성, 소음의 정도, 주파수의 떨림 강도와 관련 된 파라미터의 이상에 대하여 환자들이 보다 민감하게 인식하고 있다는 것으로 해석될 수 있다. Shim과 관련해서는 비디오스트로 보스코피(videostroboscopy)나 내시경 결과, 파킨슨병 환자에게서 후두와 호미연골(arytenoid cartilage)의 떨림이 보고되었는데(Gallena, Smith, Zeffiro, \& Ludlow, 2001; Hanson, Gerratt, \& Ward, 1984; Perez et al., 1996) 떨림으로 인한 성대 진동의 규칙성 저하는 성대의 내/외전을 통제하는 신경근육조절(neuromuscular control) 의 결함이 반영된 결과로 해석될 수 있다(Kim, 2012). Intensity와 의 상관관계는 목소리의 강도 저하가 호흡 및 발성의 중요 요소로 작용함을 보여주며 파킨슨병 환자에게 나타나는 발성부전(hypophonia)이 운동저하(hypokinesia)의 대표적인 결과물일 수 있음을 의미한다(Korean Society of Laryngology, Phoniatrics and Logopedics, 2012). 또한 앞서 언급되었던 성대 휨으로 인해 완벽한 내전
이 이루어지지 않아 발화 시 성문 틈 사이로 많은 양의 기류가 새어 나가고, 발성 강도가 감소할 수 있다(Duffy, 2005; Kang et al., 2009; Ludlow et al., 1984). FTRI와 관련해서는 앞서 집단 간 차이에서 ATRI가 중/고도집단에서 유의하게 높게 나타난 반면, 환자군 전체 의 환자-평가자 평가 간 상관관계에서는 FTRI에서 높은 상관이 나 타났다. 이는 평가자의 객관적 측정 결과, 파킨슨병이 진행됨에 따 라 진폭과 관련한 떨림의 수치가 커지지만 환자군은 기본주파수와 관련된 떨림의 문제를 좀 더 민감하게 느끼고 있는 것으로 설명 가 능하다.

전체 집단을 대상으로 하였을 때, 조음/운율은 SMR의 DDKavr, $\mathrm{DDKsdp}$, 적절한 반복 횟수, /퍼/와/커/의 적절한 반복 횟수, 문단읽 기의 전체속도, 부적절하게 삽입된 소리와 상관을 보였다. $\mathrm{SMR}$ 의 DDKavr은 모두 부적 상관관계를 보였는데 이는 반복속도가 빠를 수록 발음이 부정확하고, 말속도가 달라짐을 의미한다. SMR의 $\mathrm{DDKsdp}$ 는 모두 정적 상관관계로 확인되었는데 이는 /퍼터커/의 반복이 불규칙적일수록 발음이 부정확함을 의미하는 것으로 앞서 언급된 '조음점에 미치지 못함 현상'과 같이 SMR 수행 시 정확히 조음점을 접촉하지 않고 한 조음점 위치에서 다른 조음점 위치로 빠르게 조음기관을 움직이면서 발음하여 나타난 정적 상관의 결과 라고 할 수 있겠다(Jung et al., 2011). 또한 SMR의 규칙성과 관련해 운동저하형 마미말장애 환자군이 정상군보다 불규칙적이었다는 선행연구(Jung et al., 2011)와 일치하는 결과로, 말을 산출하는 동 안 파킨슨병 환자 스스로의 시간조절 능력(self-timing) 손상으로 정적 상관관계의 결과가 나타난 것으로 해석될 수 있다(Ackermann et al., 1997). SMR과 AMR의 /퍼/ 적절한 반복 횟수는 부정확한 발 음과 관련한 7번 문항과, /커/ 적절한 반복 횟수는 부정확한 발음과 관련한 7번문항과 말뭉침과 관련한 9번 문항과 관련해서는 모두 부적 상관을 나타났는데, 이는 적절한 반복 횟수가 적을수록 발음 이 부정확하고 말뭉침 양상이 증가하는 것을 의미한다. 또한, 읽기 과제 시 부적절하게 삽입된 소리와 달라진 말속도와 관련한 8 번 문 항과는 정적 상관관계를 보여 문단을 읽는 동안 부적절하게 삽입 된 소리가 많을수록 말속도가 달라짐을 의미한다.

보다 흥미로운 결과는 사지운동 중증에 따라자가평가척도와평 가자 측정치 간의 상관관계 양상이 상이하게 관찰되었다는 것이다. 호흡/발성의 경우 경도집단은 대부분의 문항에서 NHR이나 Shim 과의 정적 상관이 두드러졌다. 반면, 중/고도집단은 음성크기나 떨 림과 관련한 문항과 intensity만이 부적 상관관계를 보였다. 이러한 결과는 질환의 경도 수준에서는 음성의 질과 관련된 다양한 측면 에서의 결함에 대하여 인식하다가 중/고도 수준에서는 음성의 강 도 저하를 더 민감하게 인식하고 있음을 보여준다. 조음/운율의 경 
우 경도집단은 발음이 부정확하다는 호소와 $\mathrm{AMR}$ 의 /퍼/, SMR의 $\mathrm{DDKavr}, \mathrm{AMR}$ 의 /터/와/커/, SMR의 DDKsdp, AMR 중 /커/의 적 절한 반복 횟수, 문단읽기의 부적절하게 삽입된 소리 간에 상관이 두드러졌으나 중/고도집단은 말의 속도가 변하거나 말이 막히고 반복되는 양상에 대한 호소와 AMR 중 / 커/, SMR의 부적절한 반 복 횟수, $\mathrm{AMR}$ 중 /퍼/의 적절한 반복 횟수, $\mathrm{AMR}$ 중 /커/의 DDKs$\mathrm{dp}, \mathrm{SMR}$ 의 DDKavr 간에 상관을 보였다. 이는 AMR 중/커/의 DD$\mathrm{Ksdp}$ 가 두 집단 모두에서 자가평가척도의 결과와 상관관계를 보였 지만 경도집단에서는 조음의 정확성과, 중/고도집단에서는 말속도 를 포함한 운율적 측면과 관련이 있음을 시사한다. 선행연구에 의 하면 질환의 진행에 따라 부정확한 자음, 단음량, 강세 저하, 단음도 순으로 말 어려움이 나타나며(Darley et al., 1969b), 발성과 조음의 말 하위체계 손상이 선행되고, 그 영향이 운율문제로 이어진다고 보고되었다(Duffy, 2005). 따라서 상기 결과를 종합하여볼 때, 질 환의 경도 수준에서는 발음이 부정확하거나 음성과 관련된 다양 한 어려움을 호소하지만 질환이 진행되면서는 말속도나 음성 강도 의 저하를 호소할 가능성이 있으며 이것이 또한 환자의 말장애 정 도와 높은 관련성을 보이므로 평가 상황에서 평가자는 이러한 측 정치를 더 민감하게 살피고 확인해야함을 시사한다.

우리나라의 노인 인구가 꾸준히 증가함에 따라 퇴행성 질환의 발병률도 증가하고 있는 추세이며 파킨슨병 환자의 수도 역시 함 께 증가하고 있다(Korea Centers for Disease Control and Prevention, 2007). 본 연구는 평가자 중심의 말 특징 확인과 더불어 환자 중심의 심리측정적 평정을 함께 시행하여 그 관계성을 확인하였으 며, 개인의 말장애를 민감하게 인식하고 반영하는 지표가 사지운 동장애의 정도에 따라 서로 다를 수 있음을 확인하였다. 이는 임상 현장에서 전통적 방식인 평가자 중심의 평가 결과와 더불어 환자 보고에 기반한 주 호소의 중요성을 다시금 강조하였다는 것에 본 연구의 임상적 의의가 있다. 임상적 적용 측면에서는 기본 정보수 집 시 환자 본인이 느끼는 어려움에 대한 경청과 더불어 심리측정 적 방법을 활용한 해석이 결과에 포함되어야 할 필요성을 뒷받침 한다. 추후 연구를 통해 운동 증상 중증도를 보다 단계적으로 세분 화하여 질환의 경과에 따른 측정치 간의 관련성을 확인할 필요가 있겠다.

\section{REFERENCES}

Aaronson, N. K. (1988). Quality of life: what is it? How should it be measured? Oncology, 2, 69-76.

Ackermann, H., Konczak, J., \& Hertrich, I. (1997). The temporal control of repetitive articulatory movements in Parkinson's disease. Brain and Language, 56, 312-319.

Agid, Y. (1998). Levodopa is toxicity a myth? Neurology, 50, 858-863.

Ajwani, Y., \& Chand-Mall, R. (2017). Effect of speaking rate modification on articulation and pause characteristics in individuals with Parkinson's disease. Innovative Journal of Medical and Health Science, 7, 60-64.

Alexander, G. E., Crutcher, M. D., \& DeLong, M. R. (1991). Basal gangliathalamocortical circuits: parallel substrates for motor, oculomotor, "prefrontal" and "limbic" functions. Progress in Brain Research, 85, 119-146.

Barlow, S. M., Iacono, R. P., Paseman, L. A., Biswas, A., \& D’Antonio, L. (1998). The effects of posteroventral pallidotomy on force and speech aerodynamics in Parkinson's disease. In M. P. Cannito et al. (Eds.), Neuromotor speech disorders: nature, assessment and management (pp. 117-156). Baltimore, MA: Paul H. Brookes.

Bonnet, A. M., Loria, Y., Saint-Hilaire, M. H., Lhermitte, F., \& Agid, Y. (1987). Does long-term aggravation of Parkinson's disease result from nondopaminergic lesions? Neurology, 37, 1539-1539.

Boutsen, F. R. Duffy, J. R., \& Aronson, A. E. (1998). Flutter or tremor in hypokinetic dysarthria: a case study. In M. P. Cannito et al. (Eds.), Neuromotor speech disorders: nature, assessment and management (pp. 157-166). Baltimore, MA: Paul H. Brookes.

Choi, C. H., Choi, S. H., \& Lee, K. J. (2015). Speech Science. Seoul: Sigmapress. Choi, S. H. (2012). Effects of deep brain stimulation (DBS) on speech and voice in Parkinson's disease. Korean Journal of Communication \& Disorders, $17,143-155$.

Chun, E. A., Shon, Y. H., Baek, S. J., Lee, P. H., Nam, C. M., Lee, J. E., \& Choi, Y. L. (2010). Characteristics of respiration and phonation in patients with young-onset Parkinson's disease compared to normal adults. Korean Journal of Communication Disorders, 15, 537-548.

Cummings, J. L., \& Masterman, D. L. (1999). Depression in patients with Parkinson's disease. International Journal of Geriatric Psychiatry, 14, 711-718.

Darley, F. L., Aronson, A. E., \& Brown, J. R. (1969a). Clusters of deviant speech dimensions in the dysarthrias. Journal of Speech, Language, and Hearing Research, 12, 462-496.

Darley, F. L., Aronson, A. E., \& Brown, J. R. (1969b). Differential diagnostic patterns of dysarthria. Journal of Speech, Language, and Hearing Research, $12,246-269$.

Dromey, C., Kumar, R., Lang, A. E., \& Lozano, A. M. (2000). An investigation of the effects of subthalamic nucleus stimulation on acoustic measures of voice. Movement Disorders, 15, 1132-1138. 
Hyeon Ah Kim, et al. • Self-report on Speech Characteristics in Parkinson's Disease

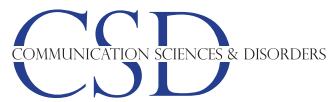

Duffy, J. R. (2005). Motor speech disorders: substrates, differential diagnosis, and management (2nd ed.). St. Louis, MO: Elsevier.

Dykstra, A. D., Hakel, M. E., \& Adams, S. G. (2007). Application of the ICF in reduced speech intelligibility in dysarthria. Seminars in Speech and Language, 28, 301-311.

Freed, D. B. (2012). Motor speech disorders: diagnosis \& treatment (2nd ed.). Clifton Park, NY: Delmar/Cengage Learning.

Gallena, S., Smith, P. J., Zeffiro, T., \& Ludlow, C. L. (2001). Effects of levodopa on laryngeal muscle activity for voice onset and offset in Parkinson disease. Journal of Speech, Language, and Hearing Research, 44, 1284-1299.

Gentil, M., Tournier, C. L., Pollak, P., \& Benabid, A. L. (1999). Effect of bilateral subthalamic nucleus stimulation and dopatherapy on oral control in Parkinson's disease. European Neurology, 42, 136-140.

Gerratt, B. R., Hanson, D. G., \& Berke, G. S. (1991). Glottographic measures of laryngeal function in individuals with abnormal motor control. In T. Baer et al. (Eds.), Laryngeal function in phonation and respiration (pp. 521532). San Diego, CA: Singular Publishing.

Goetz, C. G., Poewe, W., Rascol, O., Sampaio, C., Stebbins, G. T., Counsell, C., ... \& Yahr, M. D. (2004). Movement Disorder Society Task Force report on the Hoehn and Yahr staging scale: status and recommendations the Movement Disorder Society Task Force on rating scales for Parkinson's disease. Movement Disorders, 19, 1020-1028.

Hammen, V. L., \& Yorkston, K. M. (1996). Speech and pause characteristics following speech rate reduction in hypokinetic dysarthria. Journal of Communication Disorders, 29, 429-445.

Hanson, D. G., Gerratt, B. R., \& Ward, P. H. (1984). Cinegraphic observations of laryngeal function in Parkinson's disease. The Laryngoscope, 94, 348-353.

Hauser, R. A., Lyons, K. E., Pahwa, R., \& Zesiewicz, T. A. (2003). Parkinson’s disease: questions and answers (4th ed.). Weybridge Surrey, UK: Merit Publishing International.

Hirose, H. (1986). Pathophysiology of motor speech disorders (dysarthria). Folia Phoniatrica et Logopaedica, 38, 61-88.

Ho, S. H., Song, I. U., \& Chung, Y. A. (2016). Prognostic evaluation through cardiac 123I-metaiodobenzylguanidine image in Parkinson's disease (pilot study). Korean Journal of Clinical Geriatrics, 17, 74-78.

Jeong, J. M. (2016). Determinants of the quality of life in Parkinson's disease (PDQ-39): quality of communication life and clinical variables (Master's thesis). Yonsei University, Seoul, Korea.

Jung, E., Cho, S. R., Kim, Y., \& Kim, H. (2011). Characteristics of diadochokinesis in hypokinetic dysarthria: rate and regularity. Korean Journal of
Communication \& Disorders, 16, 74-82.

Kang, Y. (2006). A normative study of the Korean-Mini Mental State Examination (K-MMSE) in the elderly. Korean Journal of Psychology: General, $25,1-12$.

Kang, Y., Kim, Y. D., Ban, J. C., \& Seong, C. J. (2009). A comparison of the voice differences of patients with idiopathic Parkinson's disease and a normal-aging group. Phonetics and Speech Sciences, 1, 99-107.

Kang, Y., Na, D. L., \& Hahn, S. (1997). Korean version of Mini-Mental State Examination (K-MMSE). Seoul: Human Brain Research \& Consulting Co.

Kang, Y., Seong, C. J., \& Yoon, K. C. (2011). A study of prosodic features of patients with idiopathic Parkinson's disease. Phonetics and Speech Sciences, 3, 145-151.

Kee, B. S. (1996). A preliminary study for the standardization of geriatric depression scale short form-Korea version. Journal of Korean Neuropsychiatric Association, 35, 298-307.

Kim, B. M., Sohn, Y. H., Baek, S. J., Lee, P. H., Nam, C. M., Lee, J. E., \& Choi, Y. L. (2011). Characteristics of speech breathing in de novo Idiopathic Parkinson's disease during passage reading tasks. Phonetics and Speech Sciences, $3,103-110$.

Kim, H. (2012). Neurogenic speech-language disorders. Seoul: Sigmapress.

Kim, H. G., Ko, D. H., Shin, H. K., Hong, K. H., \& Seo, J. H. (1997). An experimental clinical phonetic study on patients of dysarthria, tonsilhypertrophy, nasal obstruction, and cleft palate. Speech Sciences, 2, 67-88.

Kim, H., Lee, M. S., Kim, S. W., \& Lee, W. Y. (2003). Speech rate analysis of dysarthric patients with Parkinson's disease and multiple system atrophy. Speech Sciences, 10, 221-227.

Kim, H., Lee, M. S., Kim, S. W., Choi, S. H., \& Lee, W. Y. (2004). An auditoryperceptual rating scale of dysarthric speech of patients with Parkinsonism. Speech Sciences, 11, 39-49.

Kim, K. E., \& Sim, H. S. (2001). The reading rate characteristics of adult with cerebral palsy. Journal of Special Education, 34, 49-72.

Kim, S. W., Yoon, J. H., \& Lee, S. J. (2015). Acoustic characteristics of short rushes of speech using alternate motion rates in patients with Parkinson's disease. Phonetics and Speech Sciences, 7, 55-62.

Kim, S. W., Yoon, J. H., Chang, S. E., Sohn, Y. H., Cho, S. R., \& Kim, H. (2012). The role of subcortical regions in speech production. Journal of the Korean Neurological Association, 30, 1-9.

Ko, D. H. (2015). Experimental phonetics for speech-language pathologists. Seoul: Hakjisa.

Ko, Y. M., Kim, D. Y., Choi, Y. L., \& Kim, H. H. (2010). Speech rate and pause 
characteristics in patients with Parkinson's disease. Phonetics and Speech Sciences, 2, 173-184.

Kompoliti, K., Wang, Q. E., Goetz, C. G., Leurgans, S., \& Raman, R. (2000). Effects of central dopaminergic stimulation by apomorphine on speech in Parkinson's disease. Neurology, 54, 458-458.

Korea Centers for Disease Control and Prevention. (2007). Prevalence and actual condition of Parkinson's disease. Osong: Sungkyunkwan University School of Medicine, Korea Centers for Disease Control and Prevention.

Korean Society of Laryngology, Phoniatrics and Logopedics. (2012). Understanding of laryngology. Seoul: Ilchokak.

Logemann, J. A., Fisher, H. B., Boshes, B., \& Blonsky, E. R. (1978). Frequency and cooccurrence of vocal tract dysfunctions in the speech of a large sample of Parkinson patients. Journal of Speech and Hearing Disorders, 43, 47-57.

Ludlow, C. L., Bassich, C. J., McNeil, M. R., Rosenbek, J. C., \& Aronson, A. E. (1984). Relationships between perceptual ratings and acoustic measures of hypokinetic speech. In M. R. McNeil et al. (Eds.), The dysarthrias: Physiology, acoustics, perception, management (pp. 63-195). San Diego, CA: College-Hill Press.

Martínez-Sánchez, F., Meilán, J. J. G., Carro, J., Íñiguez, C. G., Millian-Morell, L., Valverde, I. P., ... \& López, D. E. (2016). Speech rate in Parkinson's disease: a controlled study. Neurologia, 31, 466-472.

Moreau, C., Ozancak, C., Blatt, J. L., Derambure, P., Destee, A., Defebvre, L. (2007). Oral festination in Parkinson's disease: biomechanical analysis and correlation with festination and freezing of gait. Movement Disorders, 22, 1503-1506.

Narayana, S., Fox, P. T., Zhang, W., Franklin, C., Robin, D. A., Vogel, D., \& Ramig, L. O. (2010). Neural correlates of efficacy of voice therapy in Parkinson's disease identified by performance-correlation analysis. Human Brain Mapping, 31, 222-236.

Park, K. E. (2013). The effect of speech intelligibility of patients with Parkinson's disease on quality of communication life (Master's thesis). Yonsei University, Seoul, Korea.

Perez, K. S., Ramig, L. O., Smith, M. E., \& Dromey, C. (1996). The Parkinson larynx: tremor and videostroboscopic findings. Journal of Voice, 10, 354361.

Pyo, H. Y., \& Song, Y. K. (2010). Recent trends in evaluation and diagnosis of voice disorders: a literature review. Korean Journal of Communication \&
Disorders, 15, 506-525.

Ramig, L. O., Fox, C., \& Sapir, S. (2008). Speech treatment for Parkinson's disease. Expert Review of Neurotherapeutics, 8, 297-309.

Riecker, A., Kassubek, J., Gröschel, K., Grodd, W., \& Ackermann, H. (2006). The cerebral control of speech tempo: opposite relationship between speaking rate and BOLD signal changes at striatal and cerebellar structures. NeuroImage, 29, 46-53.

Sabaté, M., González, I., Ruperez, F., \& Rodríguez, M. (1996). Obstructive and restrictive pulmonary dysfunctions in Parkinson's disease. Journal of the Neurological Sciences, 138, 114-119.

Seiss, E., \& Praamstra, P. (2004). The basal ganglia and inhibitory mechanisms in response selection: evidence from subliminal priming of motor responses in Parkinson's disease. Brain, 127, 330-339.

Seol, W. (2008). Genes causing familial Parkinson's disease. Korean Journal of Psychopharmacology, 19, 29-37.

Sewall, G. K., Jiang, J., \& Ford, C. N. (2006). Clinical evaluation of Parkinson'srelated dysphonia. The Laryngoscope, 116, 1740-1744.

Shim, H. J., Park, W. K., \& Ko, D. H. (2012). Characteristics of speech intelligibility and the vowel space in patients with Parkinson's disease. Phonetics and Speech Sciences, 4, 161-169.

Shin, J. Y. (2011). The sounds of Korean. Seoul: Knowledge and Education. Theodoros, D. G., Ward, E. C., Murdoch, B. E., Silburn, P., \& Lethlean, J. (2000). The impact of pallidotomy on motor speech function in Parkinson disease. Journal of Medical Speech-Language Pathology, 8, 315-322.

Uziel, A., Bohe, M., Cadilhac, J., \& Passouant, P. (1975). Les troubles de la voix et de la parole dans les syndromes parkinsoniens. Folia Phoniatrica et Logopaedica, 27, 166-176.

Vincken, W. G., Gauthier, S. G., Dollfuss, R. E., Hanson, R. E., Darauay, C. M., \& Cosio, M. G. (1984). Involvement of upper-airway muscles in extrapyramidal disorders: a cause of airflow limitation. New England Journal of Medicine, 311, 438-442.

Yoon, J. H., Ahn, Y., Kim, S. H., Chin, J., Park, S., \& Na, D. L. (2017). Neuroanatomical correlates of hypophonia in subcortical vascular cognitive impairment. European Neurology, 78, 93-104.

Yunusova, Y., Weismer, G., Westbury, J. R., \& Lindstrom, M. J. (2008). Articulatory movements during vowels in speakers with dysarthria and healthy controls. Journal of Speech, Language, and Hearing Research, 51, 596-611. 
Hyeon Ah Kim, et al. • Self-report on Speech Characteristics in Parkinson's Disease

Appendix 1. 자가평가척도 설문지

마비말장애 자가평가척도

() 다음 문항을 읽고 발병하기 전과 비교하여 평상 시 말할 때 자신이 느끼는 것과 관련해 해당하는 곳에 $\vee$ 표시로 체크하시오.

\begin{tabular}{|c|c|c|c|c|c|c|}
\hline 문항 & 호흡 및 발성 & 전혀 그렇지 않다 & 그렇지 않다 & 보통이다 & 그렇다 & 매우 그렇다 \\
\hline 1 & 말할 때 숨이 차서 숨을 자주 쉰다 & & & & & \\
\hline 2 & 전반적인 목소리의 크기가 작다 & & & & & \\
\hline 3 & 말을 하면 목소리 크기가 점점 작아진다 & & & & & \\
\hline 4 & 바람이 새며 쉰 듯한 목소리가 난다 & & & & & \\
\hline 5 & 목소리가 떨린다 & & & & & \\
\hline 6 & 목소리 크기와 높이가 변화없이 단조롭다 & & & & & \\
\hline
\end{tabular}

\begin{tabular}{|c|c|c|c|c|c|c|}
\hline 문항 & 조음 및 운율 & 전혀 그렇지 않다 & 그렇지 않다 & 보통이다 & 그렇다 & 매우 그렇다 \\
\hline 7 & 발음이 부정확하다 & & & & & \\
\hline 8 & $\begin{array}{l}\text { 말속도가 달라졌다(말속도가 빨라짐 / 느려짐 중에 } \\
\text { 선택해주세요) }\end{array}$ & & & & & \\
\hline 9 & 말이 웅얼거리듯이 뭉쳐서 나온다 & & & & & \\
\hline 10 & 막히면서 말이 시작된다 & & & & & \\
\hline 11 & 더듬는 것처럼 말을 반복한다 & & & & & \\
\hline 12 & 말이 중간에 끊긴다 & & & & & \\
\hline
\end{tabular}




\title{
국문초록
}

\section{파킨슨병 말특성에 대한 환자 자가평가척도와 평가자 측정치의 비교}

\author{
김현아 ${ }^{1} \cdot$ 김선우 ${ }^{2}$ 윤지혜 ${ }^{3}$
}

'한림대학교 보건과학대학원 언어병리학과, ${ }^{2}$ 대림대학교 언어재활과, ${ }^{3}$ 한림대학교 언어청각학부

배경 및 목적: 파킨슨병은 말산출 시 짧고 불안정한 호흡, 발성부전, 음성떨림, 부정확한 조음, 빠른 말속도의 어려움을 보이는 것으로 알려져 있다. 말장애에 대한 객관적 측정과 주관적 평정 간에는 차이가 있을 수 있다. 본 연구는 파킨슨병 환자에게 말특성에 관한 자가 평가설문을 실시하고 임상가가 실시한 말평가 결과와의 상관관계를 살펴보았다. 방법: 파킨슨병 환자 40 명을 사지운동의 중증에 따라 경도와 중/고도의 두 집단으로 나눈 후 최대연장발성, 길항반복운동, 문단읽기의 말과제를 실시하고 CSL로 분석하였다. 자가보고설문 은 호흡/발성, 조음/운율 단계에서 주관적으로 느끼는 어려움에 대하여 5점 Likert 척도로 응답하도록 하였다. 결과: 첫째, 최대연장발 성 과제에서 Shimmer와NHR, ATRI가 길항반복운동 과제에서/퍼/와/퍼터커/ 총 반복 횟수, /퍼터커/DDKsdp가 중/고도집단에서 유 의하게 높았고, /터/, /커/ 총 반복 횟수는 중/고도집단이 유의하게 적었으며, 읽기과제에서는 집단 간 유의미한 차이가 없었다. 둘째, 중/ 고도집단은 자가보고설문에서 어려움을 더 많이 호소하였다. 셋째, 말평가 측정치와 자가보고설문의 상관관계를 살펴본 결과, 경도집 단에서는 음성과 관련된 다양한 호소나 조음정확성 항목과 말평가 측정치와의 상관이 있었고, 중/고도집단에서는 음성강도나 말속도 와 관련된 항목과 말평가 측정치와의 상관이 있었다. 논의 및 결론: 두 집단에서 말평가 측정치와 자가보고의 상관성 양상이 상이함은 파킨슨병 중증에 따라 말 어려움을 반영하는 지표가 다를 수 있음을 의미한다. 이러한 결과는 중재계획이나 예후수립에 있어 말특성 에 대한 자가인식정도를 고려해야 함을 시사한다.

핵심어: 파킨슨병, 운동저하형 마비말장애, 기기적 평가, 청지각적 평가, 자가평가척도

이 논문은 2017년도 한림대학교 교비연구비(No. HRF-201711-011)에 의하여 연구되었음.

\section{참고문헌}

강영애, 김용덕, 반재천, 성철재(2009). 파킨슨병 환자와 정상 노인의 음성비교. 말소리와 음성과학, 1, 99-107.

강영애, 성철재, 윤규철(2011). 파킨슨병 환자와 정상노인 간의 문장 읽기에 나타난 운율 특성 비교. 말소리와음성과학, 3, 145-151.

고열매, 김덕용, 최예린, 김향희(2010). 파킨슨병 환자의 말 속도와 쉼 특성. 말소리와음성과학, 2, 173-184.

김선우, 윤지혜, 이승진(2015). 파킨슨병 환자의 교대운동속도 과제에서 관찰된 ‘말 뭉침’의 음향학적 특성. 말소리와음성과학, 7, 55-62.

김선우, 윤지혜, 장수은, 손영호, 조성래, 김향희(2012). 말 산출에서 피질하 구조의 역할. 대한신경과학회지, 30, 1-9.

심희정, 박원경, 고도흥(2012). 파킨슨병 환자의 말 명료도와 모음 공간 특성. 말소리와음성과학, 4, 161-169.

유경, 장인수, 김락형(2013). 파킨슨병 환자의 음성장애지수 및 음성관련 삶의 질 연구. 동의신경정신과학회지, 24, 155-162.

정은영, 조성래, 김윤정, 김향희(2011). 운동감소형 마비말장애의 조음교대운동 특성: 속도 및 규칙성. 언어청각장애연구, 16, 74-82.

정재목(2016). 파킨슨병 삶의 질(PDQ-39)의 결정요인으로서의 의사소통 삶의 질과 임상적 특성. 연세대학교 대학원 석사학위논문. 